Article

\title{
Unpacking Resilience for Adaptation: Incorporating Practitioners' Experiences through a Transdisciplinary Approach to the Case of Drought in Chile
}

\author{
Paulina Aldunce 1,2,*, Roxana Bórquez ${ }^{1,3}$, Carolina Adler ${ }^{4}$, Gustavo Blanco ${ }^{1,5}$ and René Garreaud ${ }^{1,6}$ \\ 1 Center for Climate and Resilience Research, CR2, Blanco Encalada 2002, $4^{\circ}$ Piso, Santiago 8370449, \\ Región Metropolitana, Chile; roxana.borquez@kcl.ac.uk (R.B.); gblanco@uach.cl (G.B.); \\ rgarreau@dgf.uchile.cl (R.G.) \\ 2 Department of Environmental Science and Natural Resources, University of Chile, Av. Santa Rosa 11.315, \\ La Pintana, Santiago 8820808, Región Metropolitana, Chile \\ 3 Department of Geography, King's College London, Room K4.10, Fourth Floor, Strand Campus, \\ London WC2R 2LS, UK \\ 4 Institute for Environmental Decisions \& Transdisciplinarity Lab, ETH Zurich, Universitätstrasse 22, \\ Zurich 8092, Switzerland; carolina.adler@env.ethz.ch \\ 5 Instituto de Historia y Ciencias Sociales, Campus Isla Teja, Universidad Austral de Chile, Casilla 567, \\ Valdivia, Chile \\ 6 Departamento de Geofísica, Universidad de Chile, Blanco Encalada 2002, $4^{\circ}$ Piso, Santiago 8370449, \\ Región Metropolitana, Chile \\ * Correspondence: paldunce@uchile.cl; Tel.: +56-9-5647-3360
}

Academic Editors: Patricia Romero-Lankao, Olga Wilhelmi and Mary Hayden

Received: 30 May 2016; Accepted: 1 September 2016; Published: 6 September 2016

\begin{abstract}
Current debate on the implementation of resilience in addressing climatic impacts calls for more pragmatic means of reducing losses. In this study we aimed to generate context-specific knowledge about resilience factors for addressing the impacts of drought, with the expectation that bringing forth experiential knowledge on how impacts were addressed in the past would shed light on what constitutes key resilience factors for practitioners working in urban contexts. The study was carried in three of the largest cities in Chile: Santiago, Concepción, and Valdivia. The analytical framework consists of urban and regional resilience incorporating transdisciplinary approaches applying the Resilience-Wheel tool, combined with participatory methods for the co-production of knowledge and qualitative content analysis of documents and workshops. Results show that key determinants of building resilience to drought were: improving education and access to information, enhancing preparedness, promoting technology transfer, reinforcing organizational linkages and collaboration, decentralizing governance, and encouraging citizen participation. The Resilience-Wheel was useful for navigating the conceptual complexity and diversity of perspectives inherent among social actors. The transdisciplinary approach allowed us to co-produce key knowledge that can be applied to build resilience in future, through a bottom-up approach that bridges the science-policy interface.
\end{abstract}

Keywords: drought; Chile; climate change; resilience; urban and regional resilience; adaptation; transdisciplinarity; knowledge co-production

\section{Introduction}

As a concept, 'resilience' has increasingly influenced many fields of research, including climate change, and gained significant traction in a number of policy domains [1-3]. Given the broad diversity of perspectives, discussion also arises regarding the ambiguity of resilience definitions 
and conceptualizations, which in turn has the potential to create confusion among decision-makers and practitioners [4-9].

Several authors have proposed different approaches for navigating diverse forms of resilience in theory and practice by providing detailed reviews of the concept and its components $[7,10-13]$. Moreover, there is concrete contribution for the use of resilience in the urban context $[3,9,14-20]$. The concept of resilience becomes more specific when linked to a particular field or study object (such as cities or regions), but a heterogeneity of perspectives rooted in different research traditions is still a common feature in the literature on urban and regional resilience, similar to what is observed when applying resilience in a more general fashion [14,17].

Despite the multiple concepts attached to resilience, these studies provide a thematic structure to inform theory and assist diverse actors in the process of building resilience. For example, Aldunce and co-workers [13] analyze the use of resilience specifically in the context of climate change. In that working paper, they account for the way in which resilience has been defined and applied, identify a conceptual basis of resilience theory, systematize key determinants and attributes of resilience, and, inspired by the "Adaptive Capacity-Wheel" [21], present the 'Resilience-Wheel', a tool proposed for practical application in resilience building and assessment. The Resilience-Wheel is applied in the present study as a framework for analysis, and a detailed description of the Wheel is provided in Section 2.1.3.

Resilience building is context-dependent, sensitive to the unique social, cultural, economic, political, and physical realities, as well as the urban or rural settings in which communities are embedded $[16,17,22]$. Similarly, building resilience also depends on a unifying theme ('resilience to what') or 'boundary object' [23,24], which is an analytical concept or fulcrum of enquiry that is tangible for those participating in the process of problem-orientation in a given context, linking several intersecting viewpoints or 'worlds'. For climate change, extreme or iconic climatic events have been used as boundary objects that serve as a common point of reference and discussion, which has proved useful in putting the impacts of climate change in context [25-27]. Exploring experiences of extreme climatic events enables a more fluid dialogue with those concerned about how climate change manifests in their specific context [26] and thereby enables specific adaptation options that are locally envisioned and feasible.

Over the last seven years (2009-2015), Chile has faced the most severe drought on record, known as the 'Mega-drought', which has had profound impacts on the environment and society [28]. The labeling of this event as a 'Mega-drought' indicates the significance of this climatic phenomenon as an iconic climate event, as defined by Lynch et al. [25]. With an annual precipitation deficit between $20 \%$ and $40 \%$, the drought has been unprecedented in terms of its intensity, spatial extension, and, perhaps most importantly, its duration-one or two year-long droughts are not uncommon in Chile, but the current seven-year event is truly exceptional. The average stream flow during the period 2010-2014 declined by $30 \%-60 \%$ throughout central Chile [28]. Likewise, we have witnessed record low levels in most water reservoirs and the model-based climate projections for the 21st century consistently indicate a marked drying trend throughout the region. The effects of the mega-drought on physical systems include impacts on natural vegetation, snow pack over the Andes Mountains, surface and subsurface hydrology, and forest fires. In turn, these effects might have severe impacts on urban infrastructure and city life, such as shortages in water supplies, reduced food availability and rising prices in the cities surrounding regional agriculture production, heat waves, and increasing air pollution [28,29]. Climate change is expected to increase the frequency and magnitude of climate-related hazards such as droughts [30], with new data showing that $25 \%$ of the causes of the mega-drought can be attributed to climate change [28]. Given the high likelihood that extreme events like the current mega-drought will occur with greater frequency in the future, there is a need to move forward in the practical application of resilience, prioritizing approaches that can assist in improving responses to drought.

This paper presents the results of a participatory process, embedded in a transdisciplinary approach that generated concrete, context-specific knowledge in terms of what are the main 
impacts of the mega-drought, existing measures to address these impacts, and factors identified as supporting resilience to droughts. First, we present a detailed description of the analytical framework: transdisciplinarity and the Resilience-Wheel. Second, the research design and the methodology applied are described. Third, we delve into the results of the study and the main implications that emerged, with a focus on what these workshop results reveal in terms of relevant factors for resilience building. Finally, we conclude with a summary of lessons learned and suggestions for moving forward.

\section{Materials and Methods}

\subsection{Analytical Framework}

The analytical framework applied in this study consists of resilience, with a particular focus on urban and regional resilience, and a transdisciplinary approach. Specifically, we used the Resilience-Wheel tool, proposed by [13], combined with participatory approaches for the co-production of knowledge on relevant aspects of urban resilience.

\subsubsection{Co-Producing Knowledge through a Transdisciplinary Approach}

In this research we aimed at co-producing knowledge of what is perceived to be in the common interest in dealing with drought impacts, while taking into account the complexity of the problem and diversity of scientific perceptions of the problem, and connecting abstract and case-specific knowledge [31] (p. 35). Improving understanding of the mega-drought in Chile requires a broadening of the knowledge base to include the socioeconomic context in an integrative and systematic approach. To facilitate this process, transdisciplinary research provides what is termed policy-relevant knowledge, which is increasingly recognized as crucial for addressing problems associated with climate variability and change, such as the extreme events that characterize this mega-drought in Chile.

In generating policy-relevant knowledge, three distinct types of information are called for: (1) an understanding of the components and dynamics within and between systems (systems knowledge); (2) knowledge that helps clarify and prioritize the outcomes desired and valued by society in dealing with climate change impacts (target knowledge); and (3) knowledge of how to transform the system, for example, by informing policy options that deal with the effects and impacts of climate change in society (transformation knowledge) [32]. These three knowledge types were applied in our analytical framework as a means to structure the results of knowledge co-produced in the workshops.

\subsubsection{Urban and Regional Resilience}

Resilience has become a salient feature of the study of urban sustainability in a changing climate. However, the range of stressors and disturbances that affect cities is wide and of a heterogeneous character, including terrorism, natural hazards, economic crises, demographic change, political turmoil, etc. [16,17]. Leichenko [14] (p. 164) provides a general definition of urban resilience as "the ability of a city or urban system to withstand a wide array of shocks and stresses". In a broad sense, urban resilience is the adaptability shown by cities to face drivers leading to decline, but the components and agents on which this capacity primarily lies are a subject of controversy and vary according to different disciplinary and thematic emphases [9,33]. Leichenko [14] (p. 164) categorizes the literature on urban resilience into four large groups: (1) urban ecological resilience; (2) resilience to urban hazards and disaster risk reduction; (3) resilience of urban and regional economies; and (4) promotion of resilience through urban governance and institutions. This division is helpful to understand the different emphases authors place on the issue, but at the same time a note of caution is needed in order to avoid considering them as disconnected black boxes. In this research there are elements of the four approaches but the regional perspective is predominant. This is based on what Müller [17] argues, that is necessary to study cities nested in regions in order to understand their resilience as a consequence of multiple interactions between systems at different scales. Müller [17] 
points out the efforts made by various authors and institutions in coupling resilience thinking to urban and regional development. As noted by Reghezza-Zitt et al. [34], taking the temporal and spatial scale into account is key to understanding the dynamics of urban resilience. These authors emphasize the distinction between the intra-urban scale on one hand, and the regional, national, and global scales on the other. The adequate resilience capacity of one system - for instance, intra-urban space-does not necessarily imply resilience at the inter-urban scale. The same accounts for temporality in the process of recovery of different systems within a city, or between the city and the region in which a system is located. For example, urban forest restoration as part of greening plans might prevent heat waves in specific urban areas [35]. However, if a city is nested within a region that has suffered severe deforestation, the resilience capacity of the hinterland to heat waves is low. At this scale and in the long term, this problem might trigger rural population migration, which, in a negative feedback loop, increases demographic pressure on urban areas. Regional and long-term considerations are essential when assessing urban resilience.

\subsubsection{The Resilience-Wheel: The Components Underpinning Resilience Building}

Multi- and cross-disciplinary conceptualizations of resilience, urban resilience being no exception, lead to the generation of a great number of components (determinants) for building resilience. Aldunce et al. [13] conducted a systematic review of the literature on resilience in general (see e.g., $[5,7,10])$ and on urban resilience approaches specifically (see e.g., $[3,9,14-17,33]$ ). The results of this review were organized as a comprehensive list of determinants, understood as the characteristics repeatedly described as essential to resilience building and their various constitutive attributes necessary for the construction of each determinant (a description of these determinants and their attributes is provided in Aldunce et al. [13]. To facilitate the visualization of these determinants and their attributes, we adapted the idea captured in the "Adaptive Capacity-Wheel" proposed by Gupta et al. [21] into a 'Resilience-Wheel' (see Figure 1a,b). The two wheels are diagrammatically similar in their presentation of central components; Gupta et al.'s wheel focuses on adaptive capacity, while Aldunce et al. present a wheel composed of the core elements of resilience. The Resilience-Wheel is a flexible and easy-to-use tool that can serve to evaluate both the resilience of cities and the regions or hinterlands in which they are nested, which is the focus of the paper. Additionally, it is important to highlight that in order to work in the co-production of knowledge (transdisciplinary approach) that includes professionals, researchers, and civil society representatives coming from different disciplinary backgrounds, fields, and levels of education, what is needed is a simple tool that both is easy to understand and applies in platforms of co-production of knowledge, such as the workshops conducted in this study, but that also captures the advance in theory of urban and regional resilience. Therefore, we must make clear that the aim of the Resilience-Wheel is not to offer a completely new approach or framework for assessing and evaluating resilience; rather, it is to offer a practical and simple tool to be used in transdisciplinary processes, but including advances made by other authors regarding frameworks for analyzing and evaluating urban resilience such as ARUP The Rockefeller Foundation [3], Tyler and Moench [15], and Müller [17]. In summary, the Resilience-Wheel is a diagrammatical representation that serves as a guide for different social actors and researchers, supporting the evaluation of resilience in specific socioecological contexts at the urban scale and in the regions where they are situated [13]. When using the Resilience-Wheel, it is important to bear in mind that the incorporation of all attributes is not recommended; rather, a prioritization of those attributes most relevant in a given context is necessary. Figure $1 \mathrm{a}, \mathrm{b}$ present the resilience determinants (inner ring) and their attributes (outer ring) in the form of Social and Ecological Resilience-Wheels. 


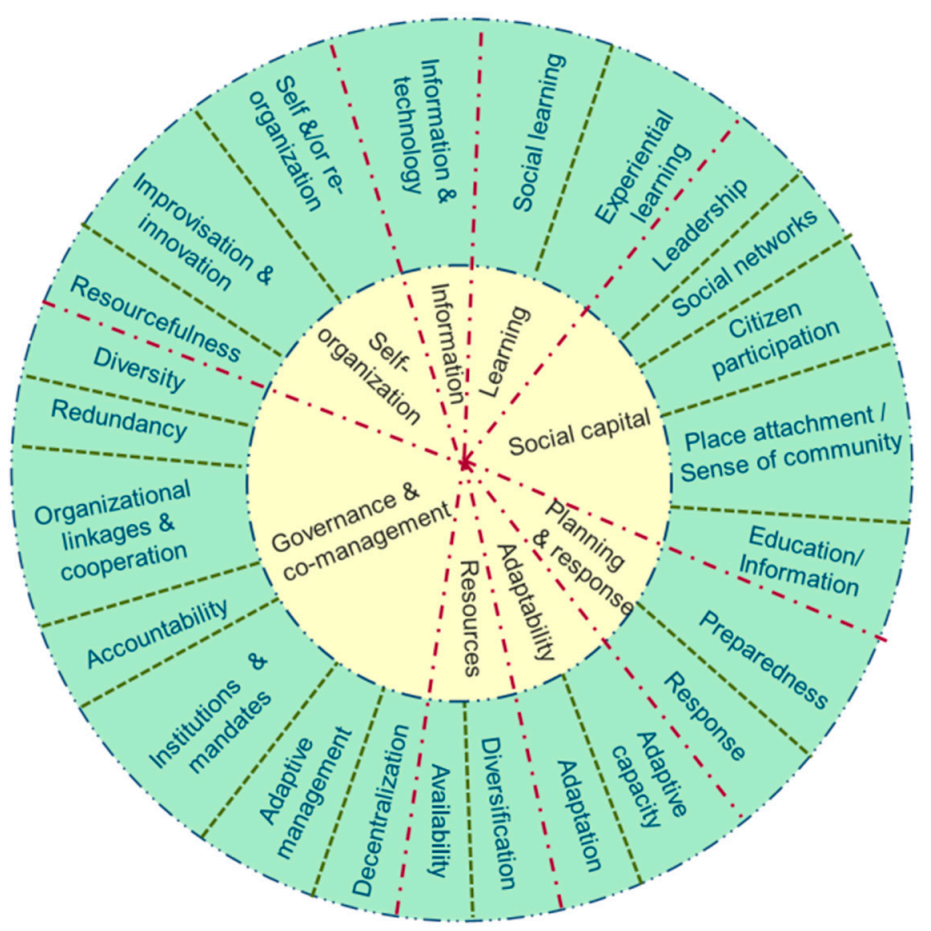

(a)

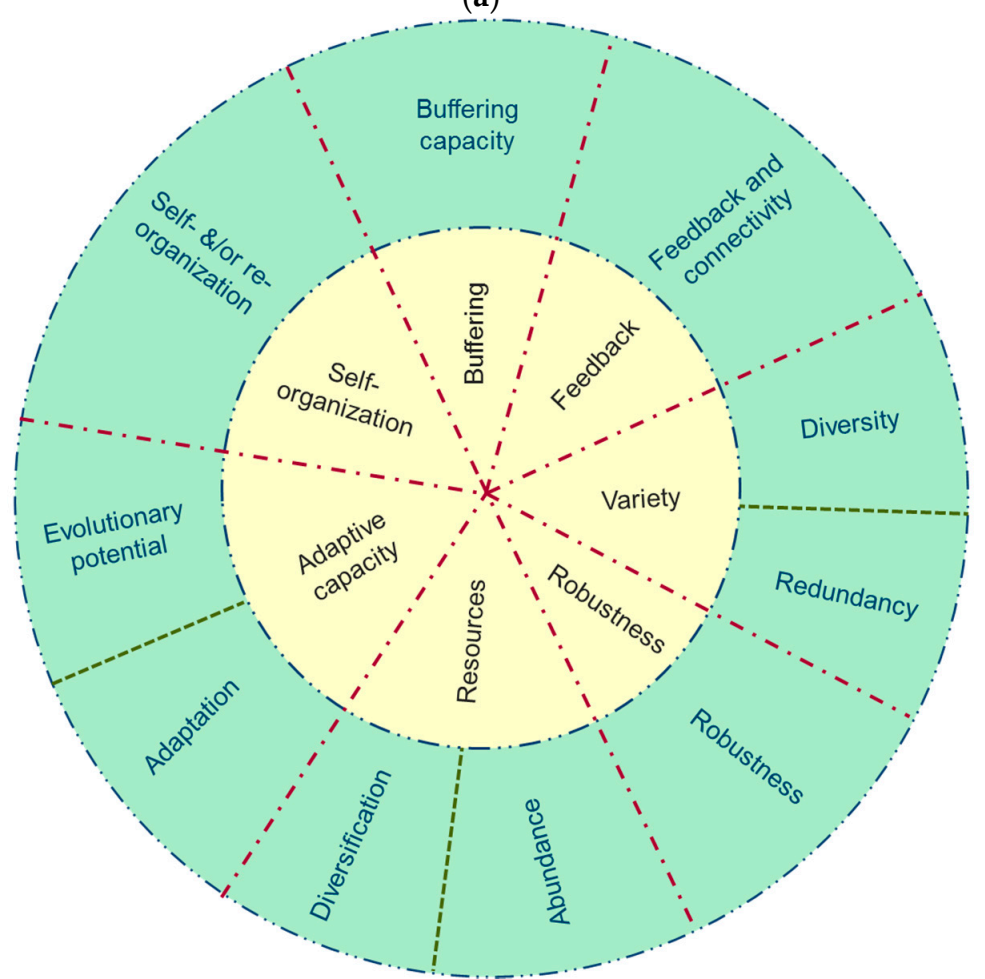

(b)

Figure 1. (a) Social Resilience-Wheel; (b) ecological Resilience-Wheel. Source: [13].

\subsection{Methodology}

The main method applied in this research was workshops, utilizing the 'mega-drought' as the boundary object to focus experiences and discussions at the workshops. We also carried out qualitative content analysis of documents and workshops, and an evaluation survey. 


\subsubsection{The Boundary Object}

The boundary object of this study is the mega-drought experienced in Chile, specifically in the following three administrative regions (equivalent to a state in the USA): Región de los Ríos, Región del Biobío, and Región Metropolitana (see Figure 2). Two of these regions were selected, given that most of the urban population of Chile lives there as they contain the largest cities in Chile: Santiago (the capital of the country and most populated city), and Concepción (the second most populated). The selection of Valdivia responds to the need of incorporating a vital mid-sized city in the south of the country. These regions and the consideration of the region scale (and not only the city scale) were chosen specifically for the case of droughts, as the regions where the cities are located play a pivotal role in providing services and products to the surrounding urban population [17]. These three cities and their regions were also selected as severe impacts of the drought are experienced here and because the three main research organizations associated with the Center for Climate and Resilience Research (CR2), in which this study was developed, are located in these regions. This enabled us to ensure the participation of relevant actors in each region. It is important to note that the Metropolitan Region has a semi-arid climate (mean annual precipitation (MAP) in Santiago: $300 \mathrm{~mm}$ ). The Region of Biobío receives more rainfall (MAP in Concepción: $1100 \mathrm{~mm}$ ) and the Los Ríos Region has a rainy climate (MAP in Valdivia: $2500 \mathrm{~mm}$ ). Despite this variation in mean annual precipitation, the effect of the mega-drought in terms of rainfall deficit is similar for the three regions [28].

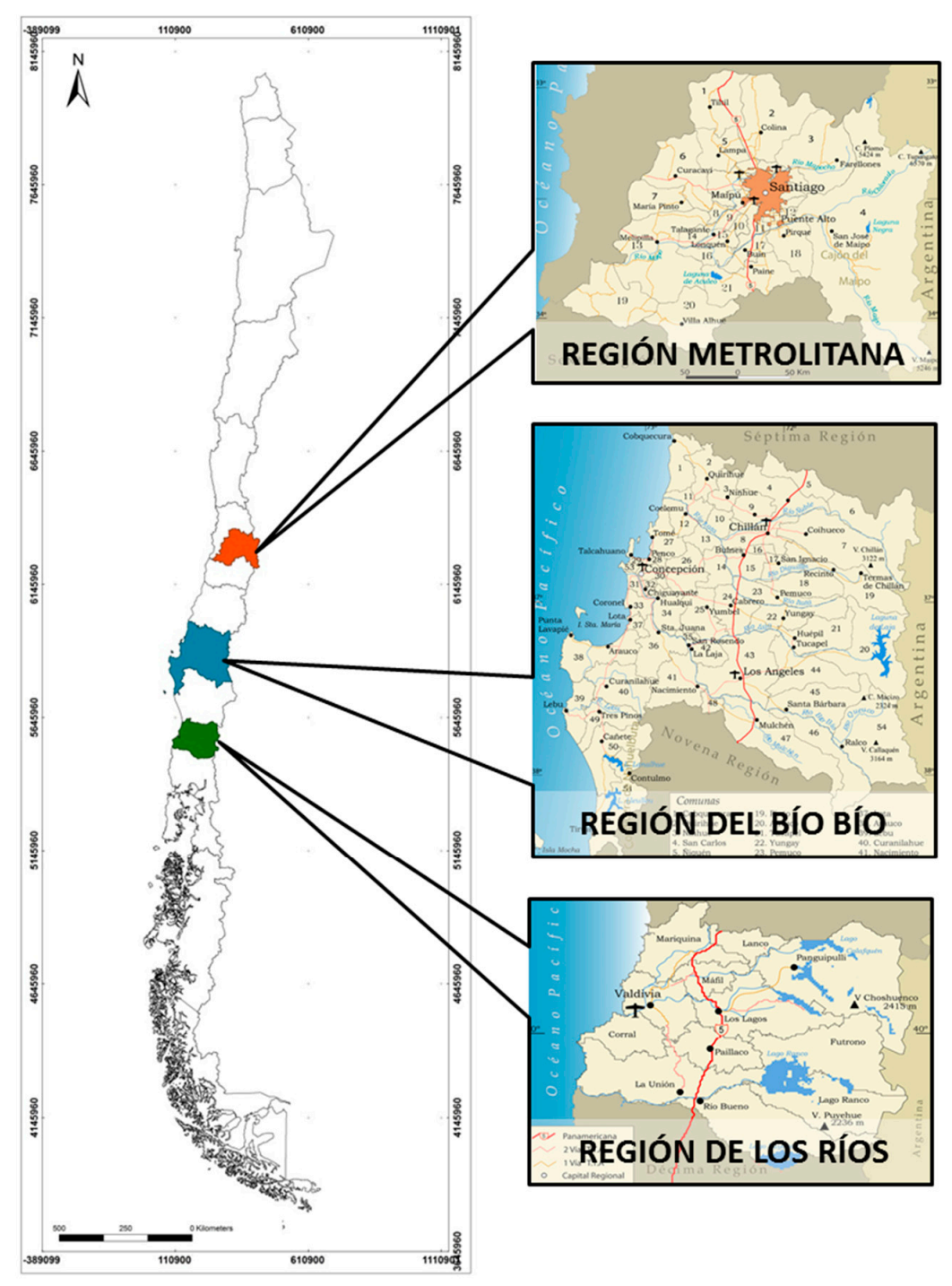

Figure 2. Map of the regions included in the study. 


\subsubsection{Selection of Study Participants}

The selection of participants took place in three stages. First, as considerations of scale are relevant [36], as well as of urban and regional resilience [17], actors from the three cities and the regions where they are located were included; specifically, in the case of the Región Metropolitana, which includes the capital city of Chile, actors from the national level were also included. Second, a diverse range of individuals and organizations dealing with drought impacts were considered, based on a preliminary review by FAO [37] and complemented by additional research. Third, following an adopted version of the actor typology proposed by [38], we included participants from four groups: government agencies, the academic sector, non-government organizations and civil society organizations, and the private sector. Invitations were delivered to 283 people, and 63 individuals agreed to participate in the workshops (the rate of participation was $21.8 \%$ ).

\subsubsection{Workshop Design, Structure, and Process}

One workshop was undertaken in each of the three regions (see Section 2.2.1). In the first part of each workshop, general information was given to participants such as scientific climate information on the mega-drought, resilience to climate change (including a presentation of the Resilience-Wheel with its determinants and attributes), and an overview of the structure and activities of the workshop. Participants were then divided into discussion groups of 10 or fewer individuals, to ensure that each participant had the opportunity to take part in the discussion. Each group was guided by a facilitator, using posters and other materials developed specifically for these workshops (see Figure 3a-c). The workshops sought to incorporate the insights, visions, attitudes, preferences, and opinions of all participants [39] (p. 191), aiming to co-produce knowledge on four topics: (a) the social, economic, environmental, and institutional impacts of drought in the participants' specific context (system knowledge); (b) what has been done to address these impacts (system knowledge) and what is valued or regarded as necessary in responding to these impacts (target knowledge) (for Topics (a) and (b), participants were asked to summarize their experiences in writing, and to include their contributions on a flipchart (see Figure 3a)); (c) the determinants and attributes for building resilience to drought (target knowledge). Here participants were asked to vote for the most relevant attributes of both Resilience-Wheels, with social and ecological subsystems (see Figure 3b); a discussion of the attributes selected followed; (d) the role of different actors in building resilience to droughts (transformation knowledge); here participants were again asked to write responses on Post-It notes, which were then posted on a flipchart (see Figure 3c).
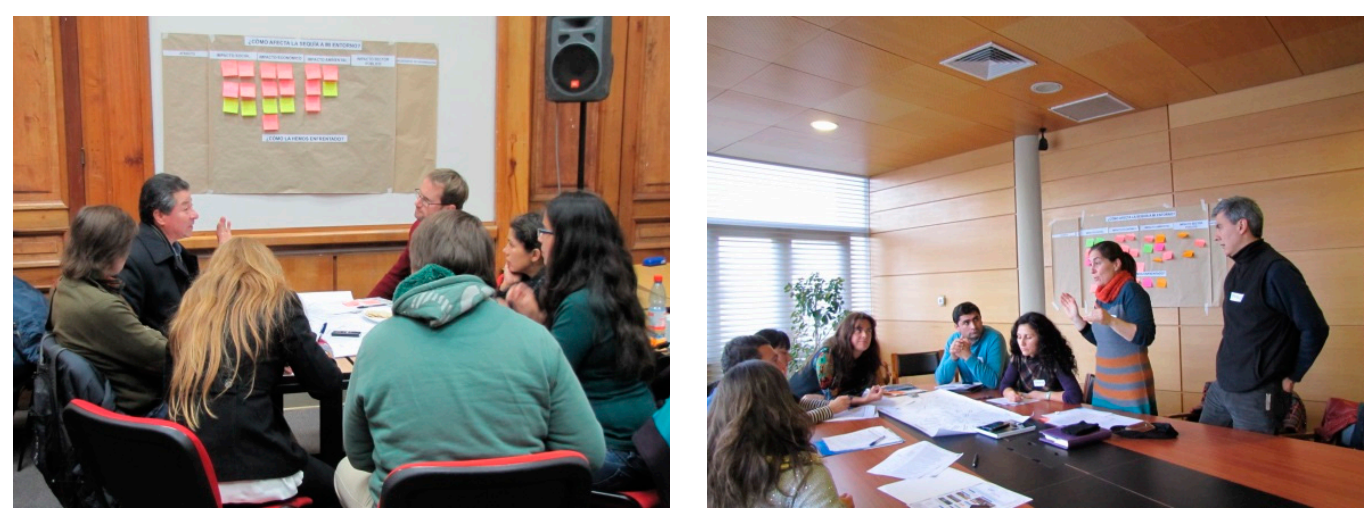

(a)

Figure 3. Cont. 

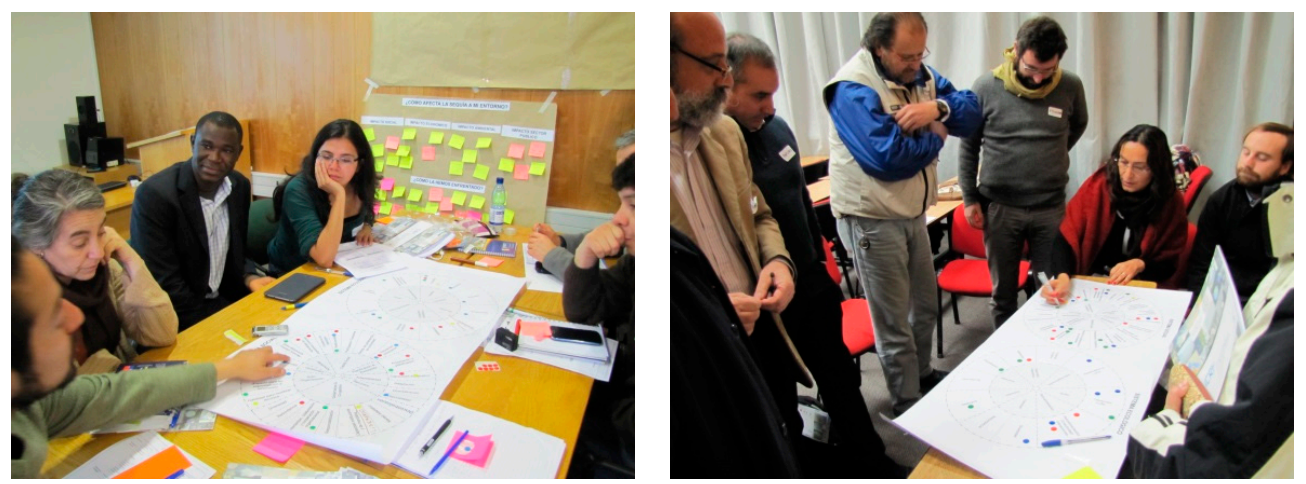

(b)
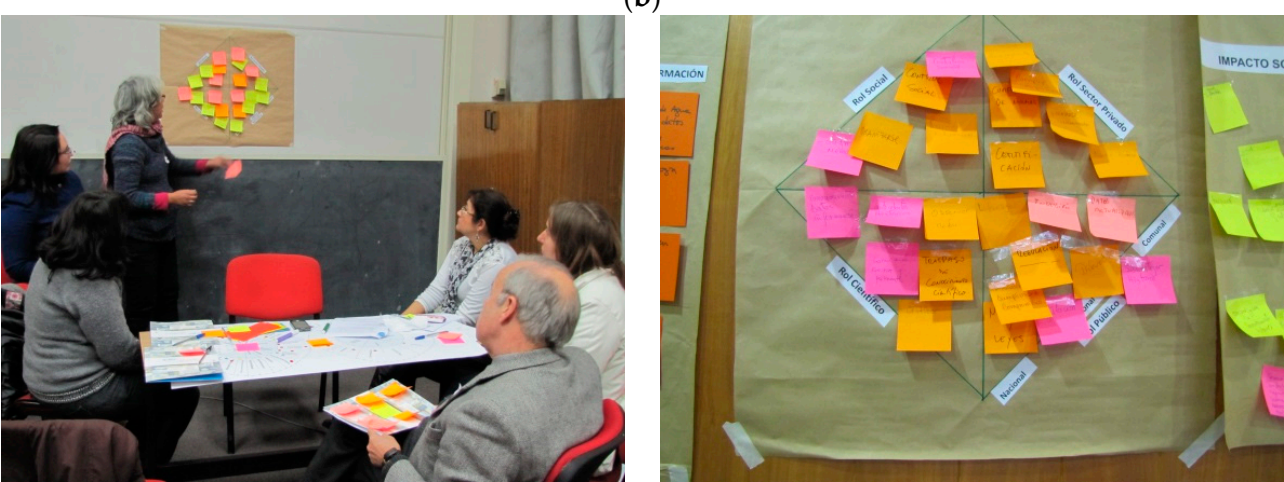

(c)

Figure 3. (a) Impacts of drought and how it is confronted; (b) prioritization of the most relevant attributes of both Resilience-Wheels, with social and ecological subsystems; (c) the role of each sector (academic, public, private, and non-government organizations and civil society) in creating resilient communities.

The workshops closed with a plenary session, where each group presented the results that emerged in their respective discussions.

The analysis involved a process of building up from the data obtained in the workshops [40], by conducting an analytical thematic coding [41] for each of the topics described above.

\section{Workshop Results and Discussion: Impacts of Drought and How to Build Resilience to It}

The main results that emerged from the three workshop are presented here, organized by the topics discussed in the workshops (see (a)-(d) above).

\subsection{How Are Droughts Experienced in Chile? System Knowledge (a)}

Table 1 presents a summary of drought impacts as identified by workshop participants in the three cities and regions.

In relation to the economic impacts of drought, impacts on the output of different products and services represent the most salient issue for all regions, followed by increased costs of production for southern regions. Impacts on agricultural production serve to illustrate the importance of focusing not only on cities when studying urban resilience, but also on the regions where they are located, given the close relationship of a system (city) nested in a larger system [17]. Cities depend on the regions where they are located because they constitute the main provider of fresh food for the urban population. Droughts have a profound effect on agricultural production and, therefore, were one of the greatest concerns expressed by participants of the workshops. The former is consistent with the study by Meza et al. [42] and Vicuña et al. [43], who found that the potential negative impact on crop production is sensitive to high seasonal water demand in Chile, which in turn is influenced by climate change-induced drought. A more optimistic interpretation is presented in the models developed 
by [44], on the basis of which the author foresees no harm to production potential in the southern regions, given the possibility of a general adaptive strategy based, for example, on implementing earlier planting dates to capture winter rains. As mentioned, economic impacts were the main concern for participants; the following quotes from participants illustrate this concern:

"... the impacts affect a specific portion of the Hualpén community, considering human and economic resources and equipment that are provided to the affected community, including water delivery trucks and potable water, among others."

"With the drought, there is an increase in the prices of agricultural products and basic services."

Table 1. Drought impacts identified by workshop participants.

\begin{tabular}{cccc}
\hline Types of Impacts & Región del Bío Bío & Región de los Ríos & Región Metropolitana \\
\hline & Production (15) & Production (11) & Production (10) \\
& Cost increment (11) & Cost increment (10) & Income (4) \\
& Water restriction (4) & Water restriction (5) & Water restriction (2) \\
Economic Impacts & Income (4) & Coping (3) & Coping (1) \\
& Employment (3) & Income (3) & Cost increment (1) \\
& Coping (1) & Employment (0) & Employment (0) \\
& Ecosystem (21) & Ecosystem (17) & Ecosystem (17) \\
\hline Environmental & Water (12) & Water (6) & Water (3) \\
Impacts & Reallocation (13) & Institutional actions (16) & Reallocation (13) \\
\hline \multirow{2}{*}{ Institutional } & Institutional actions (9) & Reallocation (12) & Institutional actions (8) \\
Impacts & Legitimacy (1) & Legitimacy (0) & Legitimacy (5) \\
& Social vulnerability (10) & Social vulnerability (11) & Social vulnerability (10) \\
& Availability of resources (9) & Availability of resources (6) & Availability of resources (9) \\
& Conflicts (5) & Cultural (5) & Conflicts (5) \\
Social Impact & Migration (3) & Migration (4) & Psychological (4) \\
& Cultural (1) & Conflicts (2) & Migration (2) \\
& Psychological (1) & Psychological (2) & Cultural (1) \\
\hline
\end{tabular}

Numbers in brackets represent the frequency of mentions for each category of impacts, by region and type of impact.

When discussing environmental issues, negative impacts on ecosystems were mentioned the most. These impacts involve ecosystem stress and damage, loss of biodiversity, increased risk of wildfire, soil degradation, land use changes, and impacts on ecosystems services in general. The impact on water availability emerged most strongly in the Región Metropolitana workshop, possibly reflecting the region's semi-arid conditions. Arguments given by participants from the three regions described a reduction of available water (both surface and subterranean sources), problems associated with water pollution, and glacial retreat. Ones again, this denotes the importance of considering the intrinsic relationship between cities and the regions that contain them as a provider of ecosystem services [17].

"... the community has been disadvantaged by the water deficit in aquifers, impacting on flora that exists principally in the Santuario Natural, as well as the green areas provided for the community's benefit."

"... an increase in the frequency, intensity, and duration of drought leads to increased frequency of fires affecting our native forests."

Regarding institutional impacts, participants of all regions identified two key impacts: the reallocation of resources and institutional actions. As suggested by Adger et al. [45], the re-allocation of resources is not necessarily a problem in itself but the timely allocation and provision of these resources is key. However, according to participant responses, re-allocation of resources has a negative connotation, likely due to the cost of using these resources for other relevant issues that need attention as well. 
"There is a re-allocation of resources in order to mitigate the effects of drought-for example, sending water tanker trucks to deliver water to communities."

"Public policy programs are affected, because they must respond to emergencies by allocating resources and altering existing plans."

Workshop participants in the three regions agreed that the two biggest social impacts relate to social vulnerability and the availability of resources; social conflicts appeared as a third factor in two of the regions (Región del Bío Bío and Región Metropolitana). This difference may be attributed to the Región de Los Ríos' large scale citizens' movement, which emerged in response to an environmental disaster in 2004. This social movement enabled a process of social learning that helped them not only face social conflict but also lessen the negative impacts of the disaster [46].

"... the lack of drinking water affects sanitation and health. There is also a migration from rural to urban areas due to the lack of system capabilities to support the entire affected population."

\subsection{Responding to Droughts: System and Target Knowledge (b)}

Table 2 presents a summary of responses on what has been done and what is needed to improve Chile's response to drought.

Table 2. Frequency of mentions of the identified impacts in participants' responses.

\begin{tabular}{ccl}
\hline Type of Drought Response & Number of Mentions & \multicolumn{1}{c}{ Description } \\
\hline Information-Education & 37 & Knowledge gaps and access to information \\
\hline Adaptation & 35 & Adaptation of communities through different practices \\
\hline Institutional & 24 & Normative and public policies \\
\hline Infrastructure & 21 & $\begin{array}{l}\text { Construction of new infrastructure to cope with drought } \\
\text { (e.g., dams, irrigation infrastructure) }\end{array}$ \\
\hline Coordination & 16 & Coordination between organizations \\
\hline Equipment and goods & 10 & Goods, equipment used to cope with drought \\
\hline Others & 5 & Other comments not corresponding to defined categories \\
\hline Services & 1 & Provisions of services \\
\hline
\end{tabular}

According to the workshop participants from the three cities and regions, a significant effort has been made to respond to the drought but further improvements are still required. First, the results emphasize the need to generate more information on, and raise awareness of, the causes and effects of drought, as well as the vulnerability of social and ecological systems. Second, participants mentioned a need for community adaptation through different practices, which is consistent not only with research findings on this topic in various regions of the country [42,47], but also with a series of concrete experiences of communities supported by international organizations and national NGOs [48,49]. Third, participants mentioned the need to improve institutional responses, in particular in relation to the adjustment of norms and regulations and the creation of flexible yet specific public policies. As has been argued, there is a need to change Chile's model of market-oriented water management, which has several negative outcomes $[48,50,51]$. The following is a quote from a participant who expressed the need to improve regulations:

"Droughts should be addressed at their corresponding scale and context, but planning does not reflect this need."

\subsection{Building Resilience to Droughts in Chile: Target Knowledge (c)}

Impacts and responses to drought identified by study participants were used as a knowledge base to move forward and direct the focus of discussion towards resilience building for urban settings, 
using the Resilience-Wheel as a guide. In this section, we present the social and ecological attributes voted on by participants, followed by a focused discussion of the social attributes.

\subsubsection{The Social Sub-System}

With regard to the social sub-system, the most frequently mentioned attributes were: education and information; preparedness; technology; organizational linkages, collaboration and cooperation; decentralization; and citizen participation (see Table 3).

Table 3. Determinants of the social sub-system and their attributes, as voted for by workshop participants.

\begin{tabular}{|c|c|c|c|c|c|}
\hline Determinant & Attribute & $\begin{array}{l}\text { Región de } \\
\text { los Ríos }\end{array}$ & $\begin{array}{l}\text { Región del } \\
\text { Biobío }\end{array}$ & $\begin{array}{c}\text { Región } \\
\text { Metropolitana }\end{array}$ & Total * \\
\hline \multirow{2}{*}{ Self-organization } & Potential for self- and/or re-organization & 3 & 0 & 1 & 4 \\
\hline & Resourcefulness & 1 & 3 & 2 & 6 \\
\hline \multirow{3}{*}{ Social capital } & Leadership & 3 & 4 & 3 & 10 \\
\hline & Education and information & 8 & 10 & 8 & $26\left(1^{\circ}\right)$ \\
\hline & Place attachment/Sense of community & 0 & 6 & 3 & 9 \\
\hline \multirow{2}{*}{ Learning } & Experiential learning & 2 & 3 & 2 & 7 \\
\hline & Social-collective memory/social learning & 4 & 0 & 0 & 4 \\
\hline Technology & Technology & 7 & 2 & 7 & $16\left(3^{\circ}\right)$ \\
\hline \multirow{7}{*}{$\begin{array}{l}\text { Governance and } \\
\text { co-management }\end{array}$} & Diversity & 1 & 0 & 2 & 3 \\
\hline & $\begin{array}{l}\text { Organizational linkages, collaboration, } \\
\text { and cooperation }\end{array}$ & 6 & 3 & 7 & $16\left(3^{\circ}\right)$ \\
\hline & Availability of institutions and mandates & 1 & 2 & 5 & 8 \\
\hline & Decentralization & 4 & 6 & 2 & $12\left(4^{\circ}\right)$ \\
\hline & Redundancy & 1 & 2 & 0 & 3 \\
\hline & Adaptive management & 2 & 1 & 3 & 6 \\
\hline & Accountability & 0 & 4 & 1 & 5 \\
\hline \multirow{2}{*}{ Resources } & Availability & 2 & 1 & 2 & 5 \\
\hline & Diversification & 0 & 0 & 0 & 0 \\
\hline
\end{tabular}

* Number in brackets represents the relative importance of the most frequently mentioned attributes (grey shading).

- Information, education $\left(1^{\circ}\right)$ and technology $\left(3^{\circ}\right)$

Two of the most frequently mentioned attributes relate to information, education, and technology. Participants stressed the relevance of timely, equitable, and universal access to information and education, and the availability of technology as fundamental for translating desirable interventions into practical applications and management for the future.

"... information allows us to focus economic resources on the affected area; for example, by precisely identifying the affected area and crops."

"Actions have a better impact and are more likely to be achieved when they are accompanied by good information and education on every level: individual and public policy."

The importance placed on these attributes by participants concurs with the literature on the role of information and education as an enabler of resilience building [7,12,52-54]. Information and education cut across multiple aspects of resilience building such as awareness, preparedness, warning, and proactivity. For example, it is critical for a proactive community to have an awareness of the hazards they face; this partly depends on the information and education available to 
them $[53,55]$. At the same time, being proactive enhances a community's capacity for anticipation and learning $[53,55,56]$. On the other hand, it is important not only to generate and disseminate information, but also to achieve symmetry of information between different stakeholders and the community, given that unequal access to information or having distorted information can result in confusion and lack of confidence among different social actors [52,57,58]. It is also important that information is delivered in a format that is accessible to the general public, and focused on concrete and relevant impacts that are specific and salient to a population.

Finally, efforts should not focus on delivering unidirectional (top-down) information (data), but rather on communicating reciprocally. In doing so, there is a greater chance for information to transform to knowledge because this information is meaningful to communities and incorporates their viewpoints, for example, in defining what information is needed and why [59]. Within the resilience literature, communication has been defined as the creation of common meanings, achieved by different actors having the opportunity to articulate their views and needs [12] (p. 140). In summary, building resilience by increasing and improving information, technology, and education represents one element of a larger transition toward increased proactivity and empowerment. This transition embodies an ambitious societal goal and one that is urgently needed but is avoided in many worldwide socioeconomic systems.

\section{- $\quad$ Preparedness $\left(2^{\circ}\right)$}

Another issue of primary concern emerging from the results refers to a shifting focus towards preparedness, not only within governments but also among other social actors such as those in the private sector, with communities at the core of this preparation. Here, a pivotal role for government agencies is providing an institutional setting that is more focused on preparation and not solely on reactive measures. On the other hand, other social actors need to develop skills and have access to resources to better respond. In this matter, resilience theory explicitly stresses the importance of adapting, preparing, and looking forward [52].

- Citizen participation $\left(4^{\circ}\right)$

A strong emphasis was placed on strengthening the role of the public and communities in building resilience, which is also stressed in the literature [12,60-62]. For example, participants indicated that community member participation in collective actions needs to be increased; there is a need for community action to improve and broaden citizen engagement, and public awareness should also be increased, consistent with what the literature states $[63,64]$.

\section{"... participation is needed in the definition of public policies and strategies. We are fighting for our values to be included."}

Participants further argued that communities represent a unique and valuable source of knowledge, that this knowledge is contextual and based on their experience in dealing with droughts, which are triggered by specific physical and social contexts. This is not only stressed by others who have arrived at similar conclusions $[10,53,58]$, but also indicates the importance of focusing on a well-defined boundary object. During the workshops, participants expressed that participation is often interpreted as merely a consultation process, used 'symbolically'. Instead, platforms and mechanisms for meaningful participation are needed so that this knowledge has a place for deliberation and integration. Moreover, the definition of common meanings by different social actors represents a key element of participation [12] because it opens up the real possibility for ideas to emerge on how to move forward and implement resilience, enabling community empowerment.

- Organizational linkages, collaboration, cooperation $\left(3^{\circ}\right)$, and decentralization $\left(4^{\circ}\right)$

The two remaining attributes identified by participants as pivotal for building resilience to drought were related to organizational linkages, collaboration and cooperation, and decentralization, which are considered within the governance and co-management determinant (see Table 3). To build resilience, flexible and adaptable decision-making processes are required and should be materialized within 
a governance framework in which multiple groups participate and cooperate in a more decentralized manner $[22,65,66]$. To enhance resilience, partnership initiatives and collaborative approaches are required to ensure multi-level, multi-sector, and cross-scale networks between actors and agencies that bring these together for mutual benefit [67].

Workshop participants also state the importance of recognizing the legitimate and distinctive roles of all actors, and the need for not only encouraging the participation of a variety of stakeholders from different levels, but also for governance structures that promote collective and shared efforts. These represent views that are also shared in the scientific literature $[10,22,58,68-70]$. For active and genuine participation, a space must be created for a more neutral negotiation and clarification of parties' respective roles and responsibilities; this clarification could emerge during and as a result of the participation process itself. However, the mere participation of different social actors in the clarification of their responsibilities does not ensure true participation; it is also crucial to consider that if devolution of responsibility is passed to non-government actors, it must be accompanied not only by sufficient and adequate support, but also by a revision and redesign of institutional arrangements [71].

Finally, decentralization is crucial for building resilience and is understood as a distribution of governance to facilitate knowledge exchange and resource sharing, and to promote local responsibility for self-management and more balanced decision-making amongst actors and across scales [72,73]. Moreover, in the highly centralized Chilean political and administrative system [74], the attribute of decentralization becomes inseparable from a broader, regional, public demand for greater participation in decision making processes (Table 3 expresses the variation between regional and metropolitan preferences). A decentralized (regional) response system might create virtuous linkages with other situated attributes such as: education, preparedness, collaboration, and public participation.

\subsubsection{The Ecological Sub-System}

For the ecological sub-system the most frequently mentioned attributes were: diversity, feedback/connectivity/interactions, adaptation, buffering capacity, evolutionary potential, and robustness (see Table 4 ).

Table 4. Attributes of the ecological sub-system, as indicated by workshop participants.

\begin{tabular}{cccccc}
\hline Determinant & Attribute & $\begin{array}{c}\text { Región de } \\
\text { Los Ríos }\end{array}$ & $\begin{array}{c}\text { Región del } \\
\text { Biobío }\end{array}$ & $\begin{array}{c}\text { Región } \\
\text { Metropolitana }\end{array}$ & Total * \\
\hline \multirow{2}{*}{ Variety } & $\begin{array}{c}\text { Diversity } \\
\text { Redundancy }\end{array}$ & 8 & 9 & 3 & $20\left(1^{\circ}\right)$ \\
& 2 & 2 & 0 & 4 \\
\hline Feedback & Feedback/ connectivity/interactions & 7 & 5 & 7 & $19\left(2^{\circ}\right)$ \\
\hline Self-organization & Self- and/or re-organization & 6 & 0 & 1 & 7 \\
\hline Adaptive & Adaptation (action) & 5 & 7 & 4 & $16\left(3^{\circ}\right)$ \\
capacity & Evolutionary potential & 1 & 6 & 4 & 7 \\
\hline \multirow{2}{*}{ Resources } & Diversification & 2 & 1 & 0 & 2 \\
\hline Robustness & Abundance & 1 & 1 & 3 & 8 \\
\hline Buffering & Robustness & 2 & 3 & 5 & $16\left(3^{\circ}\right)$ \\
\hline \multirow{2}{*}{ Number in brackets represents the relative importance of the most frequently mentioned attributes. }
\end{tabular}

\subsection{The Valued Outcomes of Different Actors in Building Resilience to Drought: Transformation Knowledge (d)}

This section presents a summary of participants' views on the role or valued outcomes that actors should aspire to and exercise for enabling resilience building. The valued outcome assigned to different actors for building resilience constitutes part of the transformation knowledge needed to move from system to target knowledge. Valued outcomes were assigned to four groups of actors: (1) non-government organizations and civil society; (2) academia and the scientific community; (3) government agencies; and (4) the private sector (see Table 5). 
Table 5. Participants' opinions on the role of different actors in building resilience (transformation knowledge).

\begin{tabular}{|c|c|c|}
\hline Valued Outcome & Participants' Arguments & Mentions \\
\hline & \multicolumn{2}{|l|}{ Value outcome for NGOs and civil society } \\
\hline Participation & To actively participate in the development and implementation of drought responses & 13 \\
\hline Rectitude & $\begin{array}{l}\text { To show rectitude and concern towards the environment and to protect it; changing } \\
\text { habits, attitudes, and customs }\end{array}$ & 12 \\
\hline Influence & Capacity of organized citizens to influence the actions or behavior of another actor & 9 \\
\hline Inquiry & Refers to the action of investigating, informing themselves, finding out, self-learning & 8 \\
\hline Self-organization & Capacity for communities to re-configure themselves proactively and modify actions & 8 \\
\hline Monitor & $\begin{array}{l}\text { To observe and check the progress or quality of something or somebody; keep under } \\
\text { systematic review }\end{array}$ & 6 \\
\hline Receptive & To be open to receiving new information from other people, organizations, or sectors. & 4 \\
\hline \multirow[t]{2}{*}{ Follow Rules } & To abide by social/normative rules & 1 \\
\hline & \multicolumn{2}{|l|}{ Value outcome for academia and the scientific community } \\
\hline Dissemination & To spread information, ensure widespread access to information & 17 \\
\hline Generate knowledge & To produce information in general & 16 \\
\hline Applied research & To develop applied research, including innovation and technology transfer & 9 \\
\hline Link & Connect with other actors in society & 7 \\
\hline Basic research & Modelling and observation, basic research & 6 \\
\hline Influence & $\begin{array}{l}\text { Ability to have an effect on people (e.g., decision-making in the private sector and in } \\
\text { municipal government) }\end{array}$ & 4 \\
\hline Teach & To teach others & 3 \\
\hline \multirow[t]{2}{*}{ Interdisciplinary } & Link with other fields of knowledge & 1 \\
\hline & \multicolumn{2}{|l|}{ Value outcome for government agencies } \\
\hline Information & To promote access to and dissemination of information and to generate information & 23 \\
\hline Planning & $\begin{array}{l}\text { The activity of improving the institutional setting and creating and implementing } \\
\text { new policies }\end{array}$ & 21 \\
\hline Regulation & A rule or the act of controlling something; to keep under systematic review & 11 \\
\hline Enabling cooperation & $\begin{array}{l}\text { To create enabling conditions for collaboration and cooperation with other actors or } \\
\text { sectors/groups }\end{array}$ & 7 \\
\hline Capacity-building & $\begin{array}{l}\text { To create enabling conditions for collaboration and cooperation with other actors or } \\
\text { sectors/groups }\end{array}$ & 7 \\
\hline Incentives & To motivate or encourage different actors to do something & 6 \\
\hline Learning & Capacity of obtaining knowledge from society & 6 \\
\hline Fund & To provide economic resources for a particular purpose & 5 \\
\hline Implement & To put (a decision, plan, agreement, etc.) into effect & 5 \\
\hline Guide & To make something move in a desired direction & 3 \\
\hline Participation & To have an proactive attitude, to participate & 3 \\
\hline \multirow[t]{2}{*}{ Accountability } & The fact or condition of being accountable; responsibility. & 1 \\
\hline & \multicolumn{2}{|l|}{ Value outcome for private sector } \\
\hline Responsibility & Good judgment and ability to act correctly and make decisions on accordingly & 17 \\
\hline Provide Information & To create and provide information for other actors in society & 11 \\
\hline Adaptation & $\begin{array}{l}\text { Act of adapting towards new technologies and processes (e.g., cleaner production } \\
\text { processes in an industry) }\end{array}$ & 9 \\
\hline Finance & To provide money for a particular purpose & 7 \\
\hline Linkage & The act of working together with other actors, sectors, or groups & 7 \\
\hline Involve & To be included, take part in, or feel part of a process & 5 \\
\hline Production & The process of making or growing goods to be sold & 3 \\
\hline Leadership & To generate leadership & 1 \\
\hline
\end{tabular}


The information presented here complements the detailed discussion of the attributes of the Social Resilience-Wheel. Participants highlighted eight aspects related to the role of non-government organizations and civil society. The three most frequently mentioned of these were "participation", "rectitude", and "influence".

\section{"Civil society have the role of seeking information and participating constructively."}

In general, the majority of the roles envisioned for the civil society and NGOs are associated with the active participation of social actors in environmental issues, with only two related to being "receptive" to receiving information and "following rules". These results are consistent with the climate change literature, which indicates that one of the current challenges of governance in climate change is to create active organizations capable of sharing experiences, generating a collective memory, and strengthening social capital [75].

Regarding the role of academia in building resilience, eight specific valued outcomes were identified (see Table 5). The notable significance and role assigned to scientists may be attributable to the recognition and legitimacy of the scientific community in the eyes of the general public and their peers [76]. Participants saw a largely unidirectional or top-down role for academia, with almost $50 \%$ considering the main role of academia to be associated with the generation of general, basic and applied research ("generate knowledge", "applied research", and "basic research"), followed by "dissemination" of information (27\%).

“... scientists are dedicated to studying and generating information. They take it and translate it into a language that can be delivered to the population."

"... scientists have the role of generating independent and credible scientific information, and disseminating this information."

The role of government agencies prompted the greatest variety of responses from participants. Promoting access to, and the generation and dissemination of "information" and "planning", were considered the most important roles, followed by "regulation".

"The state has a role in creating institutions and mandates. Although self-organization also exists, the state must fill the role of creating an environment which enables this to happen."

The roles for government can be divided into two main groups. First, $69 \%$ of participant responses are associated with a unidirectional relationship between government agencies and other actors. This is expressed as a hierarchical relationship involving top-down approaches, where agencies (the top) perform actions such as "disseminating information", "planning", "regulation", "funding", "implementing", and "guiding" in order to support society or other actors (down), who are mere recipients of that support. In the second group, comprising 30\% of responses, are roles associated with a bidirectional relationship, where agencies and other actors work together, for example, in "capacity-building" in communities, "enabling cooperation" with other actors, "incentives", "learning" from society, "accountability", and "participation". This result is relevant because the literature about participation, social learning, and governance suggests that it is necessary to move from a paternalistic and hierarchical model of the state to a mutual understanding through a bottom-up perspective in order to achieve better results in planning, mitigation and adaptation, and public policy processes in general $[75,77,78]$.

Roles assigned to the private sector for building resilience can be grouped under eight headings, where "responsibility" and "provide information" were prominent, featuring in almost 50\% of responses.

This is not unusual considering that it is generally in relation to these two issues that conflict arises because of the information asymmetries between companies and other actors and the environmental impacts caused by company activities, which are of increasing concern [79]. For this reason, companies 
have coined the concept Corporate Social Responsibility (CSR) for voluntary actions taken to adopt more socially conscious behavior and decrease the level of conflict with communities $[80,81]$. In line with this, some authors further argue that voluntary provision of information is necessary to reduce information asymmetries [82]. However, the concept of CSR has been questioned and doubts were raised about whether it truly offers a solution to social concerns $[79,81]$.

We also note that a number of valued outcomes repeat between several groups of actors. These themes emerge with slightly different names and reflect varying perspectives but nonetheless stress the widespread relevance assigned to these outcomes. One common theme is information. Knowledge generation (including research, teaching, dissemination, and outreach) is very relevant for scientists, and the private sector includes "provide information" as a key valued outcome. The other two groups assign high importance to learning and using information ("inquire" in the case of the civil society; "learning" in the case of government agencies). Another common theme is participation, a valued outcome mentioned by civil society, state agencies, and private sectors (in the form of "involve"). "Cooperation" and "linking" are valued outcomes mentioned by all actor groups except for, surprisingly, NGOs and civil society. Finally, both government agencies and the private sector mention "fund" and "finance" as important outcomes.

Overall, it is interesting to highlight that while the roles of academia, NGOs and civil society, and the private sector were mentioned 63, 61, and 60 times, respectively, the role of government agencies was mentioned close to 100 times. In the Chilean context, this is not surprising. Although the system has continued to evolve over decades, the neoliberal tradition has, on the one hand, restricted "the public sphere" to a field that is regulated by the state, while, on the other hand, restricting the NGOs and civil society to a field of private interest (individual) $[83,84]$. Despite increased levels of participation in recent years, top-down approaches remain predominant.

\section{Conclusions}

In this paper we sought to highlight the importance of participatory processes in co-producing concrete, context-specific, and relevant knowledge on resilience factors that would otherwise remain ambiguous or abstract for dealing with the impacts of drought. By way of conclusion, key insights are provided with respect to methodology, resilience theory, and practice in the context of drought in urban and peri-urban areas, and related to processes of social learning with transdisciplinarity as an overarching organizing framework for this process.

With regards to methodological improvements, key lessons emerged. First, the Resilience-Wheel was useful for navigating the conceptual complexity and diversity of perspectives inherent among social actors and academics from different disciplinary backgrounds, as well as for reaching a pragmatic consensus within a specific context. The Resilience-Wheel proved to be a powerful tool for communicating and synthesizing complex and diverse information on urban and regional resilience through a relatively simple graphical representation that may be applied elsewhere in similar contexts.

In the following paragraphs we present the implications of this research for theory and practice. Study results demonstrate the interconnectedness between urban and regional resilience. We argue that it is necessary to study cities and their surrounding regions in order to understand cities' resilience as a consequence of multiple interactions between systems at different spatial and temporal scales.

Participants' views on the most relevant impacts of drought were relatively consistent among the workshops conducted in the three regional cities. These impacts are relevant for defining system knowledge. The most significant impacts according to participant responses were: losses in production (e.g., agricultural production) and income (economic impact); negative impacts on ecosystems (environmental impact); timely access to resources for dealing with droughts (institutional impact); and increase in social vulnerability (social impact). These results provide the basis for constructing resilience in a concrete manner, e.g., 'resilience to what', which is further complemented by responses to these impacts as part of the overall system knowledge. 
Participants' responses with regard to what constitute key determinants for building resilience to drought and their attributes were a key input, as these views reflect the implicit values placed on desired outcomes (target knowledge). For the social sub-system, the most important attributes mentioned were: improving education and access to information, enhancing preparedness, promoting technology transfer, reinforcing organizational linkages and collaboration, decentralizing governance, and encouraging citizen participation. These attributes imply key considerations for solutions to address droughts (transformation knowledge), which forms the basis for evaluating the effectiveness of resilience building and thereby validates resilience theory in practice.

Based on target knowledge inputs, the impacts of droughts can be addressed through a co-production of transformation knowledge. One of the central pillars of this transformation knowledge consists of human and institutional dimensions, in which the definition of actors as agents of change requires input from relevant stakeholders. Participants identified specific roles or valued outcomes for each actor in a way that could enable resilience building, of which the most significant were: active participation in knowledge co-production (NGOs and civil society); production and dissemination of key scientific information (academia); generating and providing access to information, and creating appropriate institutional settings (government); and responsibility of companies and provision of information that they possess (private sector). This implies that changes are necessary and transforming current practices will result in differentiated responsibilities for all actors.

For building resilience, social learning processes are imperative. These processes increase the likelihood of building resilience, since they embed the context-specific expectations, capacities, experience, and knowledge of local actors. The workshops carried out in this study served as platforms for social learning where both participants and the research team learned about key determinants and attributes for building resilience to drought and the usefulness of the Resilience-Wheel in guiding them in the process of knowledge co-production.

Adopting a transdisciplinary approach allowed us to co-produce key target and system knowledge to enable a starting point for transformation knowledge. These are first steps towards improving the way in which drought is currently addressed, with a bottom-up approach to bridge the gap at the interface between science and policy.

Acknowledgments: This publication received the support of and is a contribution to the Center Resilience and Climate Research CR2 FONDAP \#1511009 and project FONDECYT N¹1140394 “Moving towards adaptation to climate change: current practices developed in Chile, their usefulness, barriers to implementation, and opportunities for improvement". We thank the participants of the three workshops for their generosity and willingness to participate.

Author Contributions: Paulina Aldunce and Roxana Bórquez conceived and designed the experiments; Paulina Aldunce and Roxana Bórquez performed the experiments; Roxana Bórquez analyzed the data; Carolina Adler and Gustavo Blanco contributed reagents/materials/analysis tools; Paulina Aldunce, Roxana Bórquez, Carolina Adler, Gustavo Blanco, and René Garreaud wrote the paper.

Conflicts of Interest: The authors declare no conflict of interest.

\section{References}

1. Department for International Development (DFID). Eliminating World Poverty: Building Our Common Future; DFID: London, UK, 2009; p. 154.

2. Pelling, M. Adaptation to Climate Change: From Resilience to Transformation; Routledge: New York, NY, USA, 2011.

3. The Rockefeller Foundation, ARUP. City Resilience Framework; The Rockefeller Foundation: New York, NY, USA, 2015.

4. Aldunce, P.; Handmer, J.; Beilin, R.; Howden, M. Is climate change framed as 'business as usual' or as a challenging issue? The practitioners' dilema. Environ. Plan. C Gov. Policy 2016. [CrossRef]

5. Brown, K.; Westaway, E. Agency, capacity, and resilience to environmental change: Lessons from human development, well-being, and disasters. Annu. Rev. Environ. Resour. 2011, 36, 321-342. [CrossRef] 
6. Cutter, S.L.; Barnes, L.; Berry, M.; Burton, C.; Evans, E.; Tate, E.; Webb, J. A place-based model for understanding community resilience to natural disasters. Glob. Environ. Chang. Hum. Policy Dimens. 2008, 18, 598-606. [CrossRef]

7. Djalante, R.; Thomalla, F. Community resilience to natural hazards and climate change: A review of definitions and operational frameworks. Asian J. Environ. Disaster Manag. 2011, 3, 339-355. [CrossRef]

8. Moser, S. Resilience in the Face of Global Environmental Change; CARRI Research Report 2; Community \& Regional Resilience Initiative: Oak Ridge, TN, USA, 2008; p. 44.

9. Méndez, R. Ciudades y metáforas: Sobre el concepto de resiliencia urbana. Ciudad Territ. Estudios Territ. 2012, 172, 215-232. (In Spanish)

10. Bahadur, A.; Ibrahim, M.; Tanner, T. The Resilience Renaissance? Unpacking of Resilience for Tackling Climate Change and Disasters; Institute of Development Studies: Brighton, UK, 2010.

11. Manyena, S.B. The concept of resilience revisited. Disasters 2006, 30, 433-450. [CrossRef] [PubMed]

12. Norris, F.H.; Stevens, S.P.; Pfefferbaum, B.; Wyche, K.F.; Pfefferbaum, R.L. Community resilience as a metaphor, theory, set of capacities, and strategy for disaster readiness. Am. J. Commun. Psychol. 2008, 41, 127-150. [CrossRef] [PubMed]

13. Aldunce, P.; Indvik, K.; Borquez, R.; Adler, C.; Galaz, V. Resilience in the Context of Climate Change: Structuring Diversity Through a Systematic Review of the Literature; CR2: Santiago, Chile, 2014.

14. Leichenko, R. Climate change and urban resilience. Curr. Opin. Environ. Sustain. 2011, 3, 164-168. [CrossRef]

15. Tyler, S.; Moench, M. A framework for urban climate resilience. Clim. Dev. 2012, 4, 311-326. [CrossRef]

16. Metzner-Szigeth, A. Contradictory approaches? On realism and constructivism in the social science research on risk, technology and the environment. Futures 2009, 41, 156-170. [CrossRef]

17. Müller, B. Urban and regional resilience-A new catchword or a consistent concept for research and practice? In Urban Resilience: How do Cities and Regions Deal with Change; Müller, B., Ed.; German Annual of Spatial Research and Policy Series; Springer: Berlin, Germany, 2011.

18. Polsky, C.; Neff, R.; Yarnal, B. Building comparable global change vulnerability assessments: The vulnerability scoping diagram. Glob. Environ. Chang. 2007, 17, 472-485. [CrossRef]

19. Haase, D.; Frantzeskaki, N.; Elmqvist, T. Ecosystem services in urban landscapes: Practical applications and governance implications. Ambio 2014, 43, 407-412. [CrossRef] [PubMed]

20. Chelleri, L. Urban Resilience Trade-offs: Sfide Derivate Dall'Applicazione di un Approccio Integrato Alla Resilienza Urbana (Urban Resilience Trade-offs: Challenges in Applying an Integrated Approach to Urban Resilience); GSSI Cities Working Papers; Social Science Electronic Publishing, Inc.: Rochester, NY, USA, 2015.

21. Gupta, J.; Termeer, C.; Klostermann, J.; Meijerink, S.; van den Brink, M.; Jong, P.; Nooteboom, S.; Bergsma, E. The adaptive capacity wheel: A method to assess the inherent characteristics of institutions to enable the adaptive capacity of society. Environ. Sci. Policy 2010, 13, 459-471. [CrossRef]

22. Gaillard, J.C. Vulnerability, capacity and resilience: Perspectives for climate and development policy. J. Int. Dev. 2010, 22, 218-232. [CrossRef]

23. Star, S.; Griesemer, J. Institutional ecology, 'translations' and boundary objects: Amateurs and professionals in berkeley's museum of vertebrate zoology, 1907-1939. Soc. Stud. Sci. 1989, 19, 387-420. [CrossRef]

24. Gieryn, T. Boundary-work and the demarcation of science from non-science: Strains and interests in professional ideologies of scientists. Am. Sociol. Rev. 1983, 48, 781-795. [CrossRef]

25. Lynch, A.; Tryhorn, L.; Abramson, R. Working at the boundary: Facilitating interdisciplinarity in climate change adaptation research. Bull. Am. Meteorol. Soc. 2008, 89, 169-179. [CrossRef]

26. Adler, C.; McEvoy, D.; Chhetri, P.; Kruk, E. The role of tourism in a changing climate for conservation and development. A problem-oriented study in the Kailash sacred landscape, Nepal. Policy Sci. 2012, 46, 161-178. [CrossRef]

27. Roman, C.E.; Lynch, A.H.; Dominey-Howes, D. What is the goal? Framing the climate change adaptation question through a problem-oriented approach. Weather Clim. Soc. 2010, 3, 16-30. [CrossRef]

28. Garreaud, R.; Aldunce, P.; Araya, G.; Blanco, G.; Boisier, J.; Bozkurt, D.; Carmona, A.; Christie, D.; Farías, L.; Gallardo, L.; et al. La Mega-Sequia 2010-2015: Una Lección Para el Futuro; Center for Climate and Resilience Research- CR2: Santiago, Chile, 2015; p. 26. (In Spanish)

29. Barata, M.; Ligeti, E.; De Simone, G.; Dickinson, T.; Jack, D.; Penney, J.; Rahman, M.; Zimmerman, R. Climate change and human health in cities. In Climate Change and Cities: First Assessment Report of the Urban Climate Change Research Network; Rosenzweig, C., Solecki, W., Hammer, S., Mehrotra, S., Eds.; Cambridge University Press: Cambridge, UK, 2011; pp. 179-213. 
30. IPCC Intergovernmental Panel on Climate Change. Climate Change 2013: The Physical Science Basis. Contribution of Working Group I to the Fifth Assessment Report of the Intergovernmental Panel on Climate Change; Cambridge University Press: Cambridge, UK, 2013; p. 1535.

31. Pohl, C.; Hirsch Hadorn, G. Principles for Designing Transdisciplinary Research. Proposed by the Swiss Academies of Arts and Sciences; Oekom: Munich, Germany, 2007.

32. Hadorn, G.H.; Biber-Klemm, S.; Grossenbacher-Mansuy, W.; Hoffmann-Riem, H.; Joye, D.; Pohl, C.; Wiesmann, U.; Zemp, E. Handbook of Transdisciplinary Research; Springer: Berlin, Germany, 2008; p. 448.

33. Campanella, T.J. Urban resilience and the recovery of New Orleans. J. Am. Plan. Assoc. 2006, 72, 141-146. [CrossRef]

34. Reghezza-Zitt, M.; Rufat, S.; Djament-Tran, G.; Le Blanc, A.; Lhomme, S. What resilience is not: Uses and abuses. Cybergeo Eur. J. Geogr. 2012. [CrossRef]

35. McPhearson, P.T. Toward a sustainable New York city: Greening through urban forest restoration. In Sustainability in America's Cities; Springer: Washington, DC, USA, 2011; pp. 181-203.

36. Nelson, D.; Adger, N.; Brown, K. Adaptation to environmental change: Contributions of a resilience framework. Annu. Rev. Environ. Resour. 2007, 32, 395-419. [CrossRef]

37. FAO Organización de Las Naciones Unidas para la Agricultura y la Alimentación. Gestión del Riesgo de Sequía y Otros Eventos Climáticos Extremos en Chile, Estudio Piloto Sobre la Vulnerabilidad y la Gestión Local del Riesgo; FAO: Santiago, Chile, 2010; p. 140. (In Spanish)

38. Cornell, S.; Berkhout, F.; Tuinstra, W. Opening up knowledge systems for better responses to global environmental change. Environ. Sci. Policy 2013, 28, 60-70. [CrossRef]

39. Tàbara, J.D. Participación cualitativa y evaluación integrada del medio ambiente y de la sostenibilidad. Aspectos metodológicos en cuatro estudios de caso. Doc. Anàlisi Geogr. 2003, 42, 183-213. (In Spanish)

40. Creswell, W.; Piano Clark, V. Examining preliminary considerations. In Designing and Conducting Mixed Methods Research; Sage Publications: Thousand Oaks, CA, USA, 2007; pp. 20-37.

41. Richards, L. Handling Qualitative Data: A Practical Guide; Sage Publications: London, UK, 2009.

42. Meza, F.; Wilks, D.; Gurovich, L.; Bambach, N. Impacts of climate change on irrigated agriculture in the Maipo basin, Chile: Reliability of water rights and changes in the demand for irrigation. J. Water Resour. Plan. Manag. 2012, 138, 421-430. [CrossRef]

43. Vicuña, S.; McPhee, J.; Garreaud, R. Agriculture vulnerability to climate change in a snowmelt-driven basin in semiarid Chile. J. Water Resour. Plan. Manag. 2012, 138, 431-441. [CrossRef]

44. Agricultura y Medio Ambiente (AGRIMED). Análisis de Vulnerabilidad del Sector Silvoagropecuario, Recursos Hídricos y Edáficos de Chile Frente a Escenarios de Cambio Climático; Universidad de Chile: Santiago, Chile, 2008; p. 181. (In Spanish)

45. Adger, W.N.; Barnett, J.; Brown, K.; Marshall, N.; O’Brien, K. Cultural dimensions of climate change impacts and adaptation. Nat. Clim. Chang. 2013, 3, 112-117. [CrossRef]

46. Sepúlveda, C.; Villarroel, P. Swans, conflicts, and resonance: Local movements and the reform of Chilean environmental institutions. Latin Am. Perspect. 2012, 39, 181-200. [CrossRef]

47. Budds, J. Contested $\mathrm{H}_{2} \mathrm{O}$ : Science, policy and politics in water resources management in Chile. Geoforum 2009, 40, 418-430. [CrossRef]

48. Villarroel, C. Asociaciones Comunitarias de Agua Potable Rural En Chile: Diagnóstico y Desafíos; FENAPRU, Chile Sustentable, Heinrich Böll Stiftung: Santiago, Chile, 2012. (In Spanish)

49. Frêne, C.; Ojeda, G.; Santibáñez, J.; Donoso, C.; Sanzana, J.; Molina, C.; Andrade, P.; Núñez-Ávila, M. Agua en Chile: Diagnósticos Territoriales y Propuestas Para Enfrentar la Crisis Hídrica; Agua que has de beber: Valdivia, Chile, 2014; p. 58. (In Spanish)

50. Ortíz, A. La legislación hidrológica orientada al libre mercado como modelo de reformas en los países andinos: Planteamiento del problema. Cuad. Desarro. Rural 2008, 5, 87-111. (In Spanish)

51. Bauer, C. The experience of water markets and the market model in Chile. In Water Trading and Global Water Scarcity: International Experiences; Maestu, J., Ed.; Routledge: Abingdon, UK, 2012; pp. 130-143.

52. Aldunce, P.; Beilin, R.; Handmer, J.; Howden, M. Resilience for disaster risk management in a changing climate: Practitioners' frames and practices. Glob. Environ. Chang. 2015, 30, 1-11. [CrossRef]

53. Paton, D.; Johnston, D. Disaster Resilience: An Integrated Approach; Charles, C., Ed.; Thomas Publisher: Springfield, IL, USA, 2006. 
54. United Nations International Strategy for Disaster Reduction (UN/ISDR). Hyogo Framework for Action 2005-2015: Building Resilience of Nations and Communities to Disasters; United Nations International Strategy for Disaster Reduction (UN/ISDR): Geneva, Switzerland, 2007; p. 25.

55. Handmer, J.; Dovers, R. A typology of resilience: Rethinking institutions for sustainable development. Organ. Environ. 1996, 9, 482-511. [CrossRef]

56. Klein, R.; Nicholls, R.; Thomalla, F. Resilience to natural hazards: How useful is the concept? Environ. Hazards 2003, 5, 35-45. [CrossRef]

57. Handmer, J.; Dovers, R. Handbook of Disaster and Emergency Policies and Institutions; Earthscan: London, UK, 2007; p. 187.

58. O'Brien, G.; O'Keefe, P.; Gadema, Z.; Swords, J. Approaching disaster management through social learning. Disaster Prev. Mag. 2010, 19, 498-508. [CrossRef]

59. McNie, E. Reconciling the supply of scientific information with user demands: An analysis of the problem and review of the literature. Environ. Sci. Policy 2007, 10, 17-38. [CrossRef]

60. Bird, D.; Gisladottir, G.; Dominey-Howes, D. Different communities, different perspectives: Issues affecting residents' response to a volcanic eruption in southern Iceland. Bull. Vulcanol. 2011, 73, 1209-1227. [CrossRef]

61. Pfefferbaum, B.; Reissman, D.; Pfefferbaum, R.; Klomp, R.; Gurwitch, R. Building resilience to mass trauma events. In Handbook on Injury and Violence Prevention Interventions; Doll, L., Bonzo, S., Mercy, J., Sleet, D., Eds.; Kluwer Academic Publishers: New York, NY, USA, 2005; pp. 347-358.

62. Haque, C.E.; Etkin, D. People and community as constituent parts of hazards: The significance of societal dimensions in hazards analysis. Nat. Hazards 2007, 41, 271-282. [CrossRef]

63. Brown, A.; Dayal, A.; Rumbaitis Del Río, C. From practice to theory: Emerging lessons from Asia for building urban climate change resilience. Environ. Urban. 2012, 24, 531-556. [CrossRef]

64. Shaw, K.; Theobald, K. Resilient local government and climate change interventions in the UK. Local Environ. 2011, 16, 1-15. [CrossRef]

65. Barnett, J. Adapting to climate change in Pacific Island countries: The problem of uncertainty. World Dev. 2001, 29, 977-993. [CrossRef]

66. Dovers, S. Normalizing adaptation. Glob. Environ. Chang. 2009, 19, 4-6. [CrossRef]

67. Adger, W.N.; Brown, K.; Nelson, D.R.; Berkes, F.; Eakin, H.; Folke, C.; Galvin, K.; Gunderson, L.; Goulden, M.; O’Brien, K.; et al. Resilience implications of policy responses to climate change. Wiley Interdiscip. Rev. Clim. Chang. 2011, 2, 757-766. [CrossRef]

68. Beilin, R.; Sysak, T.; Hill, S. Farmers and perverse outcomes: The quest for food and energy security, emissions and climate adaptation. Glob. Environ. Chang. 2012, 22, 463-471. [CrossRef]

69. Thomalla, F.; Larsen, R.K. Resilience in the context of tsunami early warning systems and community disaster preparedness in the Indian Ocean Region. Environ. Hazards 2010, 9, 249-265. [CrossRef]

70. Twigg, J. Characteristics of a Disaster-Resilience Community: A Guidance Note; DFID Disaster Risk Reduction Interagency Coordination Group: Benfield, UK, 2007.

71. Collins, K.; Ison, R. Jumping off arnstein's ladder: Social learning as a new policy paradigm for climate change adaptation. Environ. Policy Gov. 2009, 19, 358-373. [CrossRef]

72. Djordjević, S.; Butler, D.; Gourbesville, P.; Mark, O.; Pasche, E. New policies to deal with climate change and other drivers impacting on resilience to flooding in urban areas: The CORFU approach. Environ. Sci. Policy 2011, 14, 864-873. [CrossRef]

73. Ebi, K. Resilience to the health risks of extreme weather events in a changing climate in the United States. Int. J. Environ. Res. Public Health 2011, 8, 4582. [CrossRef] [PubMed]

74. Thayer Correa, L.E. Descentralización y desarrollo regional en Chile: Una mirada desde la sociedad. Polis 2011, 10, 267-287. (In Spanish) [CrossRef]

75. Pahl-Wostl, C.; Craps, M.; Dewulf, A.; Mostert, E.; Tabara, D.; Taillieu, T. Social learning and water resources management. Ecol. Soc. 2007, 12, 5.

76. Fourez, G. La Construcción del Conocimiento Científico, Sociología y Ética de la Ciencia, 3rd ed.; Narcea: Madrid, Spain, 2000. (In Spanish)

77. Broto, V.; Boyd, E.; Ensor, J. Participatory urban planning for climate change adaptation in coastal cities: Lessons from a pilot experience in Maputo, Mozambique. Curr. Opin. Environ. Sustain. 2015, 13, 11-18. [CrossRef] 
78. Goldthau, A. Rethinking the governance of energy infrastructure: Scale, decentralization and polycentrism. Energy Res. Soc. Sci. 2014, 1, 134-140. [CrossRef]

79. Jo, H.; Song, M.; Tsang, A. Corporate social responsibility and stakeholder governance around the world. Glob. Financ. J. 2016, 29, 42-69. [CrossRef]

80. Barnea, A.; Rubin, A. Corporate social responsibility as a conflict between shareholders. J. Bus. Ethics 2010, 97, 71-86. [CrossRef]

81. Horowitz, L. Culturally articulated neoliberalisation: Corporate social responsibility and the capture of indigenous legitimacy in new Caledonia. Trans. Inst. Br. Geogr. 2015, 40, 88-101. [CrossRef]

82. Martínez-Ferrero, J.; Ruiz-Cano, D.; García-Sánchez, I. The causal link between sustainable disclosure and information asymmetry: The moderating role of the stakeholder protection context. Corp. Soc. Responsib. Environ. Manag. 2015. [CrossRef]

83. De la maza, G. Espacio público y participación ciudadana en la gestión pública en chile: Límites y posibilidades. Polis 2011, 10, 45-75. (In Spanish) [CrossRef]

84. Klesner, J.L. Social capital and political participation in Latin America: Evidence from Argentina, Chile, Mexico, and Peru. Latin Am. Res. Rev. 2007, 42, 1-32. [CrossRef]

(C) 2016 by the authors; licensee MDPI, Basel, Switzerland. This article is an open access article distributed under the terms and conditions of the Creative Commons Attribution (CC-BY) license (http:/ / creativecommons.org/licenses/by/4.0/). 